\title{
大曰歯部の咬合支持が失われた状態で 咬合高径の温存を選択した咬合再構成症例
}

A case of occlusal reconstruction without bite raising for a patient with loss of occlusal support

江本 寛 $^{*}$
Hiroshi Emoto
Takuya Shimada

Keyword : occlusal vertical dimension, bite raising, diagnostic waxing キーワード: 咬合高径, 咬合挙上, 診断用ワックスアップ

In the case of a full mouth restoration, if there is no apparent reduction in the vertical dimension, opportune bite raising upon crown restoration should be kept to minimum. However, whether to preserve vertical dimension or to raise the bite can be a delicate question when the clinical crown length is not sufficient. This report is to present a case of occlusal reconstruction for a 58-year-old female patient with little posterior occlusal support. The initial plan was to restore the function of the molar with full-mouth restoration. After careful consideration on the pros and cons of bite raising by diagnostic wax-up, a full mouth restoration was performed while preserving the vertical dimension despite the short crown length. As a result, minimally invasive full-mouth restoration was achieved while preserving tooth structure and pulp.

全顎にわたる補緅治療を行う場合, 顔貌などから明らかな垂直顎間距離の短縮がない場合には, 歯冠修復の 便宜上の咬合挙上は，最少限にすべきだと考えられる，しかし，臨床歯冠長の短い場合には，咬合高径を温存 するか, あるいは咬合を挙上するか, 判断に苦しむことが多い. 本症例（患者：58 歳, 女性）は, 大臼歯部の 咬合支持をほぼ失っていたために全顎的な補綴処置で機能回復を計画したが, 診断用ワックスアップにより咬 合挙上の得失を慎重に検討し, 歯冠長が短かかったにもかかわらず咬合高径を温存したまま全顎的な補緅処置 を行った，その結果，歯質・歯䯣の保存を重視した，ミニマムインターベンションの全顎的補綴治療を実現す ることができた。【顎咬合誌 $40(1 \cdot 2): 45-52,2020 】$

緒言

咬合再構成を行うには, (1)臼歯部における咬合の安定, (2)顎関節部の維持・安定, (3)上顎中切歯の切端と口唇か ら口元の調和を含めた前歯部の審美性を確保すること， (4)咬合高径と上下顎の水平的な位置関係, (5)前歯部誘導 路の付与を検討すべきである 1〜3).

\footnotetext{
*江本歯科医院 **島田歯科医院

T 651-2211 兵庫県神戸市西区押部谷町栄 141-1 ₹ 581-0081 大阪府八尾市南本町 1-9-7
}

本症例においては，大臼歯部の咬合支持が失われ（1) の条件で不利), 残存している歯冠長が短いため審美性 と臼歯離開咬合を与えることが困難である（3，（5)の条 件で不利)。また(2)，(4)の条件は，一般的に経年的変化 や患者の年齢, 生活環境にも影響されるものであると共 に，経過を長期に観察するべき項目でもある，そこで, 咬合再構成の条件(1)～(5)を全て具備しするためには咬合 挙上が必要になると思われた。しかし, 明らかな咬合の 低下が認められる場合を除き, 補綴処理の便宜のために 咬合を挙上することは, 咀嚼筋との調和, そして顎関節 との調和，歯周支持組織の負担という観点から避けられ 
るべきであり，どうしても必要な場合でも最小限にすべ きだとされている4).そこで, 既存の咬合高径にて治 療計画・最終補緅設計が可能かを検討する必要があった. 今回著者らは, 咬合を挙上して最終補緅物に移行した場 合の診断用ワックスアップと既存の咬合高径にて作製し た場合の診断用ワックスアップを比較し, 咬合再構成の 条件(1)〜 (5)を具備できる最終補綴物の形態を模索した.

本症例においては, 現在の咬合高径を維持した状態で も機能的・審美的に患者の満足度の高い補綴治療ができ ることが確認できたので報告する.

\section{症例}

\section{症例概要}

初診日：平成 28 年 12 月

患者: 58 歳, 女性（図 1)

職業：教師

主訴：上の前歯の差し歯がとれて，歯ぐきが腫れて
いる.

既往歴 : 25 年前に卵巣膿腫の手術を受けているが, 全身的な問題はない.

患者の希望 : 歯がボロボロなのを何年も放置してし まったので，できる限りしっかりと治したい。

現症

パノラマエックス線写真（図 2）からは臼歯部の咬合 崩壊, 咬合平面の不揃いが見られ, 口腔内写真（図 3) からはし1歯根破折によると思われる根尖部に㿉孔が認め られ， $87 \mid 7 ， \overline{8 \mid 78}$ j蝕, 4 , 5 補綴物脱離， 65 , 6 の欠損が放置されたため, 臼歯部の咬合支持が失われた 状態であった。 上顎前歯部のフレアアウトは認められな かった、顎関節の C T 画像を図 4 に示す。矢状断像から 下顎頭の大きさに左右差が認められるものの, 下顎頭の 輪郭も鮮明で形態異常や吸収像もみられず，下顎窩との 間隙（関節隙）も正常範囲内だと考える。前頭断像から

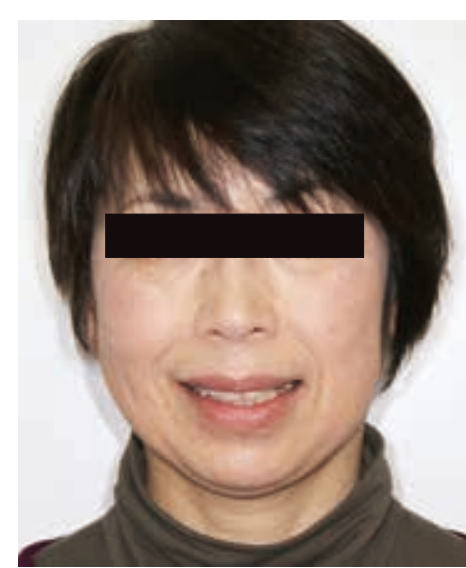

図 1 初診時の正面顔貌写真

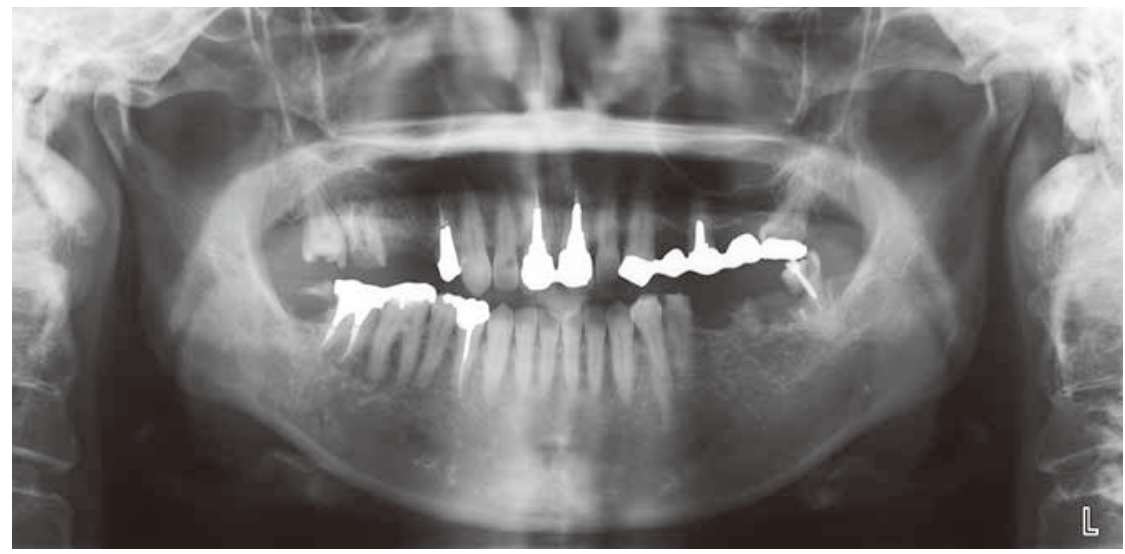

図 2 初診時のパノラマエックス線写真

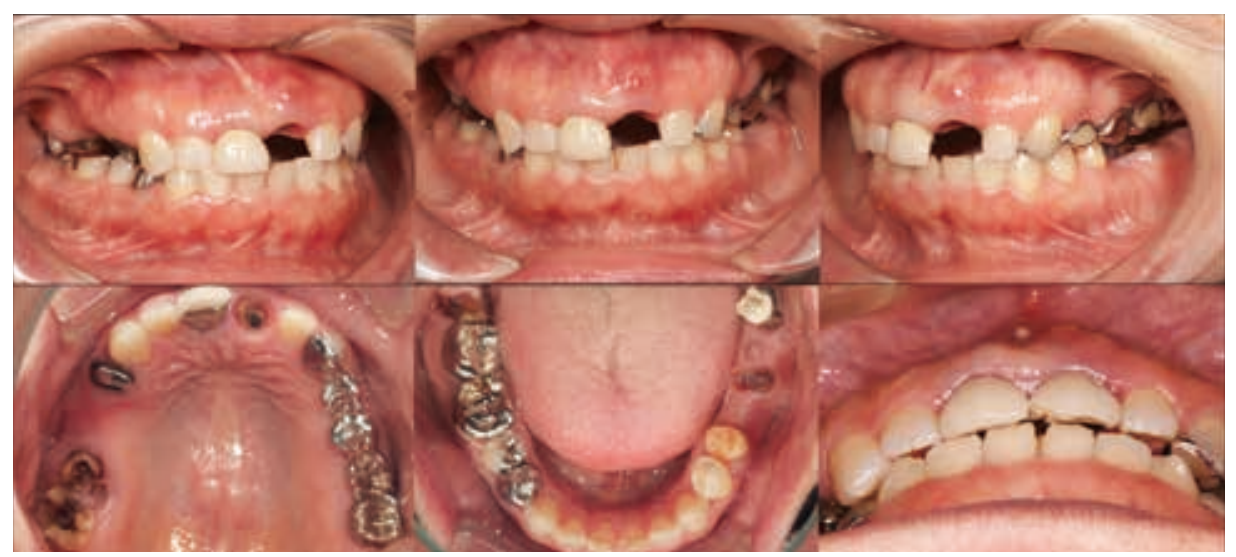

図 3 初診時の口腔内写真 
も下顎頭の内外側的中央部で関節陌は正常に認められる. 顎関節症状はなかった。

歯周組織検査（表 1）からは 87|57, 87|に $4 \mathrm{~mm}$ のプロービングの深さ (PPD) が存在し, 若干の出血部 位も認められたが, 動摇度を含め大きな問題はなかった.

\section{診査・診断}

\section{顔貌所見（図 1)}

下顎がやや左側に偏位, 瞳孔間線と口唇線のバランス は正常の範囲内であった. 正中線もわずかに左側に偏位 が認められるが許容範囲と判断した.

Esthetic line (E-Line) 5) は, 上口唇まで $4 \mathrm{~mm}$ 下口 唇まで $2 \mathrm{~mm}$ 内側にあるのが美しいとされている. 図 5 に初診時の顔貌を提示する. 臼井 6) は日本人の場合, E-Line 付近に上下の口唇が位置するのが良好と報告し ている. 本症例は, ほぼ正常と診断した。

\section{口腔内所見}

島田ら 7) は日本人における上顎 6 前歯の長径に対す る幅径の比で割った縦横比は， $0.83 \sim 0.86$ が良好とし ているが, この患者では, 歯冠の長径と幅径のバランス が右上中切歯で $1.25,\lfloor$ が 1.14 と悪く, 長径が極端に 短い。また，臼歯部においても歯冠長が極端に短い．欠 損部に対合する歯の挺出のため咬合平面の乱れも認めら れた. 歯周病は歯肉溝の深さが 1 以外の全ての歯におい て 2〜 4mm で歯槽骨の状態も良好である.

\section{診断}

長期的に臼歯部欠損の放置, う蝕の放置のため臼歯部 の咬合支持が培失し下顎前歯が上顎前歯を突き上げ，ま た 1 が歯根破折し唇側の歯槽骨が大きく吸収されたと診 断した.

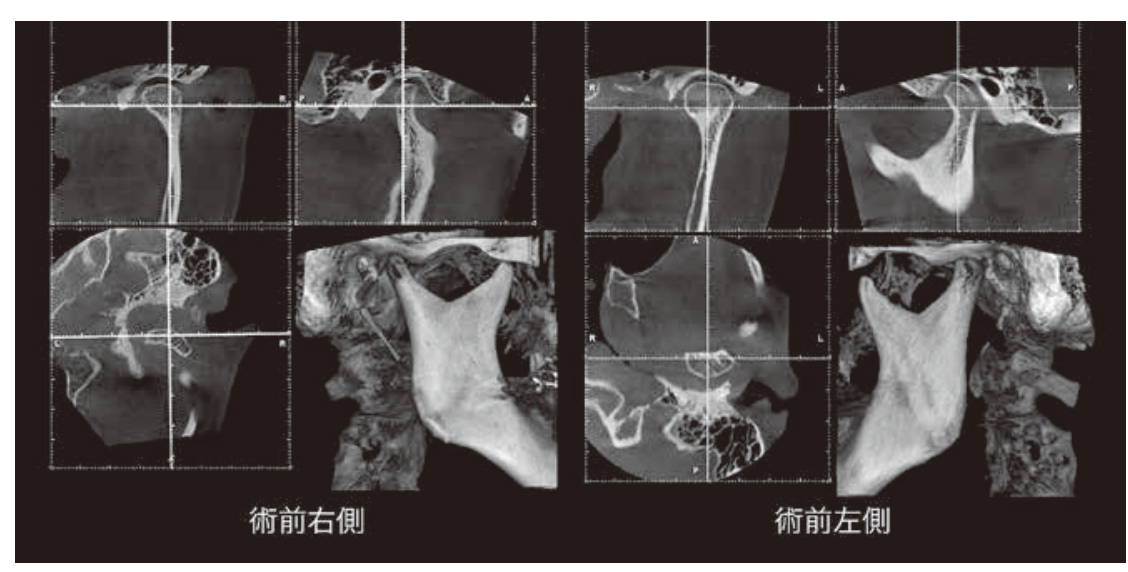

図 4 初診時の顎関節 CT 像

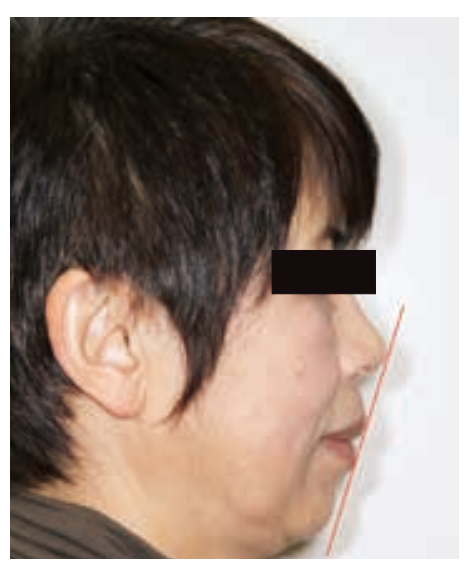

図 5 初診時の側貌写真

表 1 初診時歯周組織検査

\begin{tabular}{|c|c|c|c|c|c|c|c|c|c|c|c|c|c|c|c|c|}
\hline Mobility & 0 & 0 & & & 0 & 0 & 0 & 0 & 0 & 0 & 0 & & 0 & & 0 & \\
\hline $\mathrm{PPD}(\mathrm{B})$ & (324) & 434 & & & 323 & 222 & 222 & 222 & 35.4 & 322 & 323 & & 433 & & 8134 & \\
\hline \multirow[t]{2}{*}{$P P D(P)$} & 434 & 434 & & & 323 & 222 & 222 & 222 & 333 & 323 & 223 & & (3) 23 & & $\$ 33$ & \\
\hline & 8 & 7 & 6 & 5 & 4 & 3 & 2 & 1 & 1 & 2 & 3 & 4 & 5 & 6 & 7 & 8 \\
\hline $\mathrm{PPD}(\mathrm{L})$ & 434 & 434 & 333 & 333 & 323 & 222 & 222 & 222 & 222 & 222 & 222 & 323 & 223 & & 222 & 222 \\
\hline $\mathrm{PPD}(\mathrm{B})$ & 444 & 833 & 333 & 333 & 323 & 222 & 222 & 222 & 222 & 222 & 222 & 223 & 222 & & 222 & 222 \\
\hline Mobility & 0 & 0 & 0 & 0 & 0 & 0 & 0 & 0 & 0 & 0 & 0 & 0 & 0 & & 0 & 0 \\
\hline
\end{tabular}




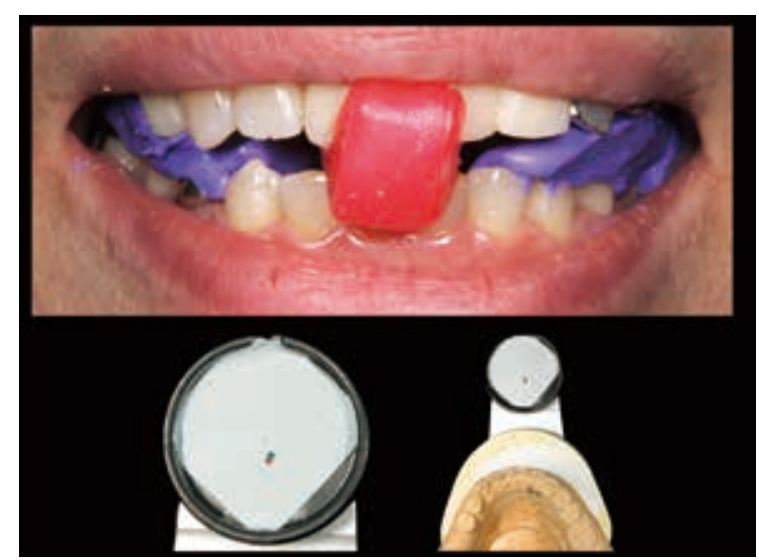

図 6 上：下顎位の採得 ( $\mathrm{CR}$ バイト), 下：中心咬合 位（緑点）と中心位（赤点）の位置を確認

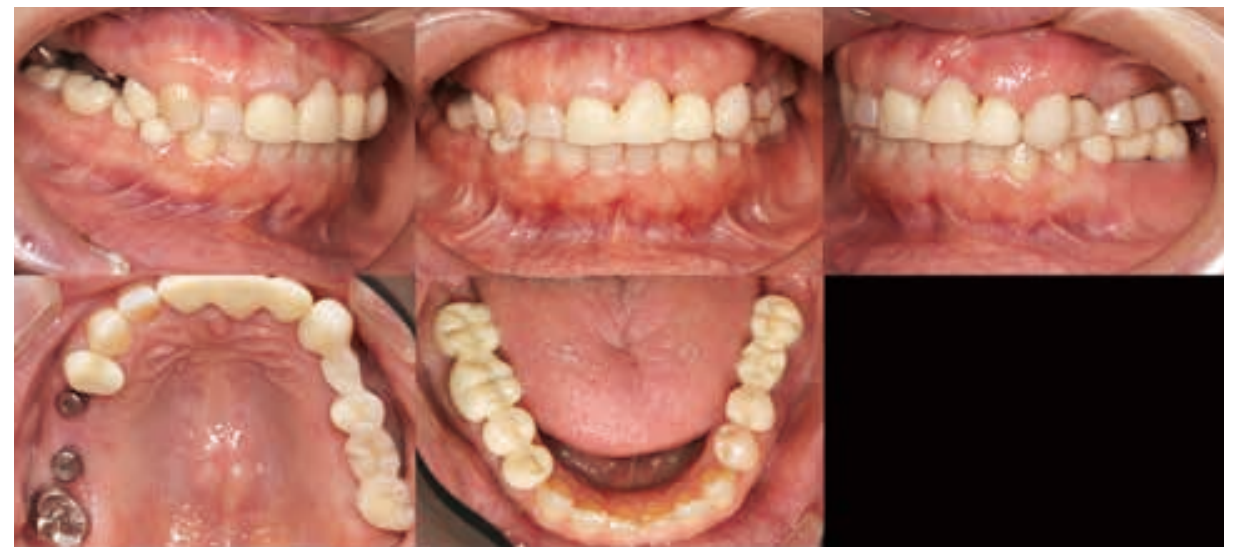

図 7 インプラントの埋入とファーストプロビジョナルレストレーション

\section{咬合診査}

中心位の採得はチンポイント変法 8) を用いて採得し た。菅野は下顎誘導法のチンポイント変法は, 下顎が咀 嚼関連筋群の緊張のバランスによって位置づけられてい ることから，生理的緊張をできるだけ変化させないよう に, 患者自身に閉口を指示するのではなく, 術者がオ トガイ下部に人差し指をそっと添えて下顎を上下的に誘 導するとしている。咬合採得後にはフェイスボウトラ ンスファーにより咬合器（PROTARevo.7：KaVo 社）に マウントし, 中心咬合位と中心位の位置を確認した。 図 6 に中心咬合位と中心位の差異を示す。赤い点が中心位, 緑の点が中心咬合位で両者に差異は認められなかった。

\section{治療計画}

予後不良歯である 7 ， 11， 8178 を抜歯し， 75 部，
446 部, $\longdiv { 6 7 }$ 部にインプラントの埋入を行い, (060) インプラントブリッジ， 囵|10)ブリッジ， 84|357, $7654 \mid 5$ はオールセラミックスにより修復する計画を たてた.

\section{治療経過}

予後不良歯である $71,4 ， \overline{8} \mid 78$ を抜歯した後，図 7 に示すように@(1) 10のプロビジョナルレストレーション を装着し，既存の咬合高径を維持するため，8にに金銀パ ラジウム合金にて作製した全部鋳造冠を仮着した。その 後は順次既存の補綴物をはずしてプロビジョナルレス トレーションに置き換え， 75 部，46 部， 67 部にイ ンプラントの埋入を行った（図 7). 図 8 はこの段階で, 32」，引により維持されている咬合高径にて行った診 断用ワックスアップを示す．側方運動時における歯 離開に不安があったため図 9 に示す天然歯である 32 ， 


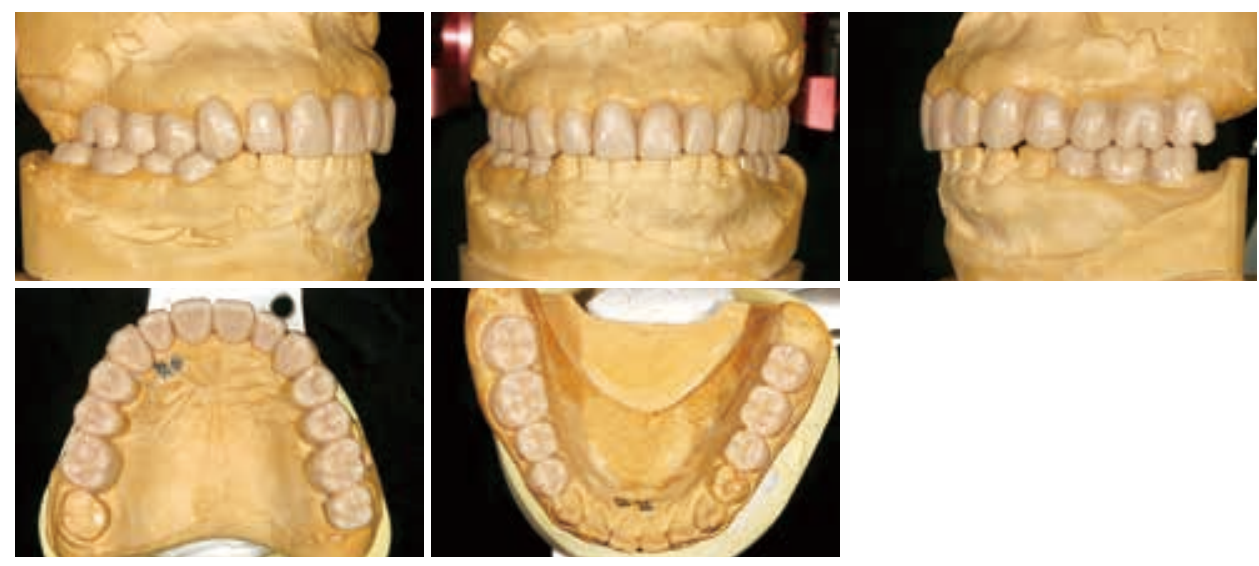

図 8 既存の咬合高径による診断用ワックスアップを作成

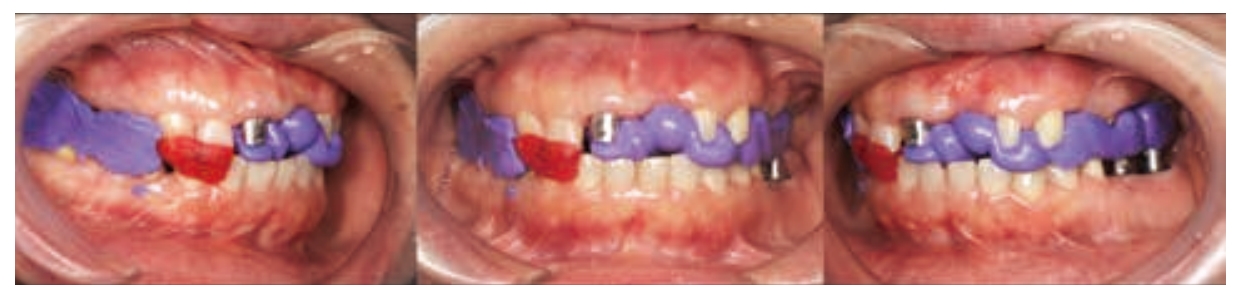

図 9 32, 3 3にレジンバイトにて $1.5 \mathrm{~mm}$ 咬合挙上しシリコーンバイトを採得
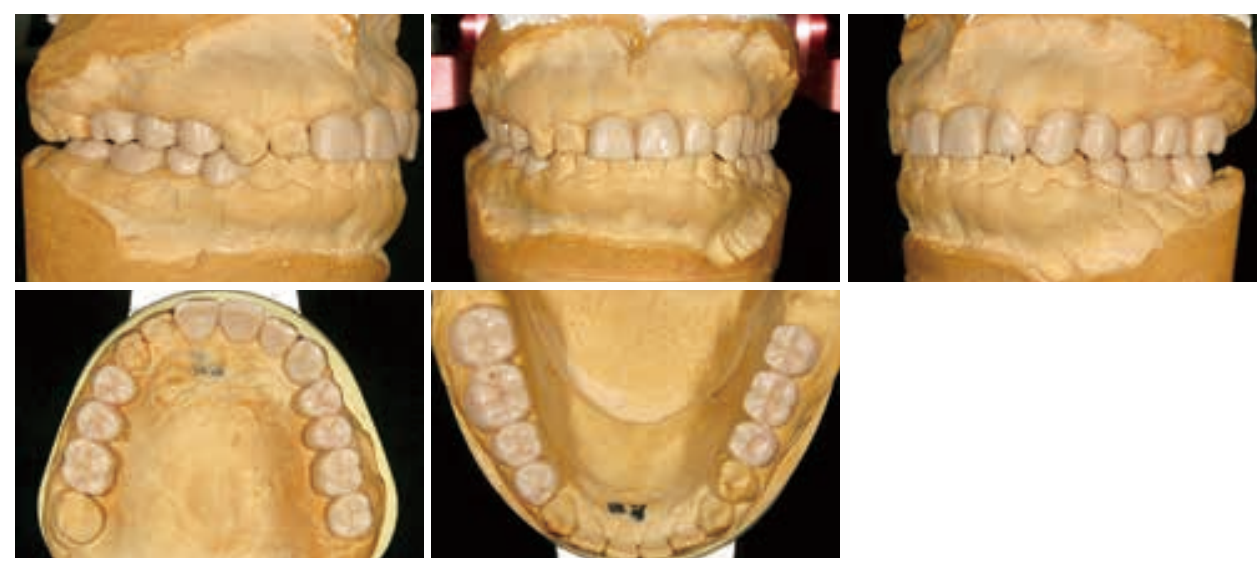

図 10 右側犬歯部で $1.5 \mathrm{~mm}$ 挙上した診断用ワックスアップ

3を基準にレジンバイトにて $1.5 \mathrm{~mm}$ 咬合を挙上し，こ の状態で再度作製した診断用ワックスアップを図 10 に 示す。咬合挙上しない状態（図 8）と挙上した状態（図 10）での診断用ワックスアップを比較, 検討した結果, 挙上しない状態でも側方運動時に臼歯離開が確保できる と判断できたので, 咬合は挙上せずに既存の咬合高径に て治療を行うこととした。

また， 111 の歯頸線ラインが不揃いであったため審 美性を考慮し, 図 10 の診断用ワックスアップを基に 図 11 に示すサージカルガイドを作製し 321 の歯周外 科（歯冠長延長術）を行った. 切開直後を図 12 に示す. 歯間乳頭を温存するために大きく剥離することはなく, サージカルガイドを装着し, 歯槽骨の削除量を決定した.
JIADS 歯周外科用バー（コメット社）を用いて，1mm 骨の削合を行い縫合した。

インプラントと骨との結合を埋入後 4 カ月待った後, セカンドプロビジョナルレストレーションを装着（図 13）した。この状態で 3 力月経過観察を行い, 水平的 な顎位のズレや顎関節等に特に異常が認められなかった ため最終補経物（図 14）に移行した。咬合を挙上しな かったが，側方運動時の臼歯部離開が獲得できたと考え る。最終補綴物装着時のパノラマエックス線写真を図 15 に, 顔貌写真を図 16 に示す。術前（図 4）と術後 （図 17）の顎関節の CT 像を矢状断像および前頭断像か ら比較しても関節隙の変化は認められなかった．以上の ことから，(1)且歯部における咬合の安定を回復，(2)顎 


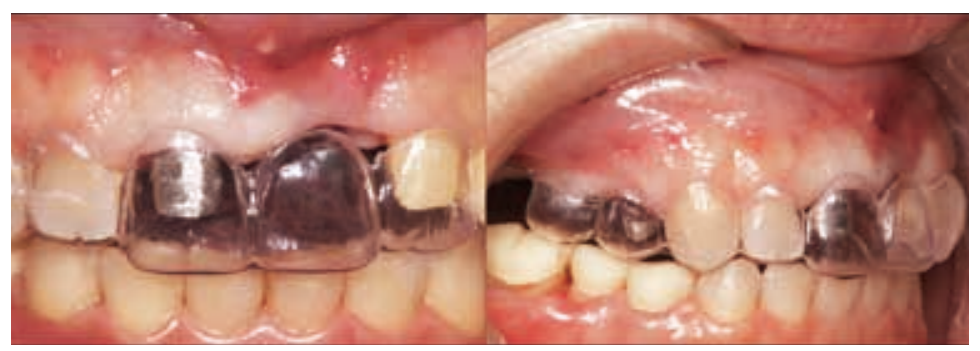

図11 321 歯冠長延長術のためのサージカルガイド

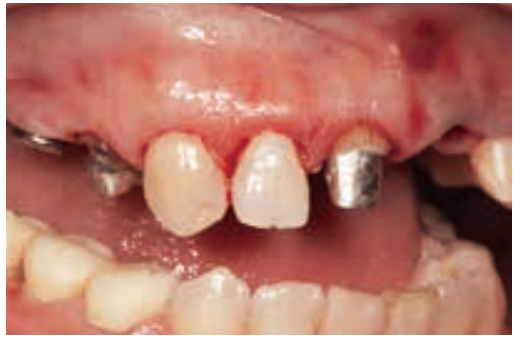

図 12 歯冠長延長術の手術時

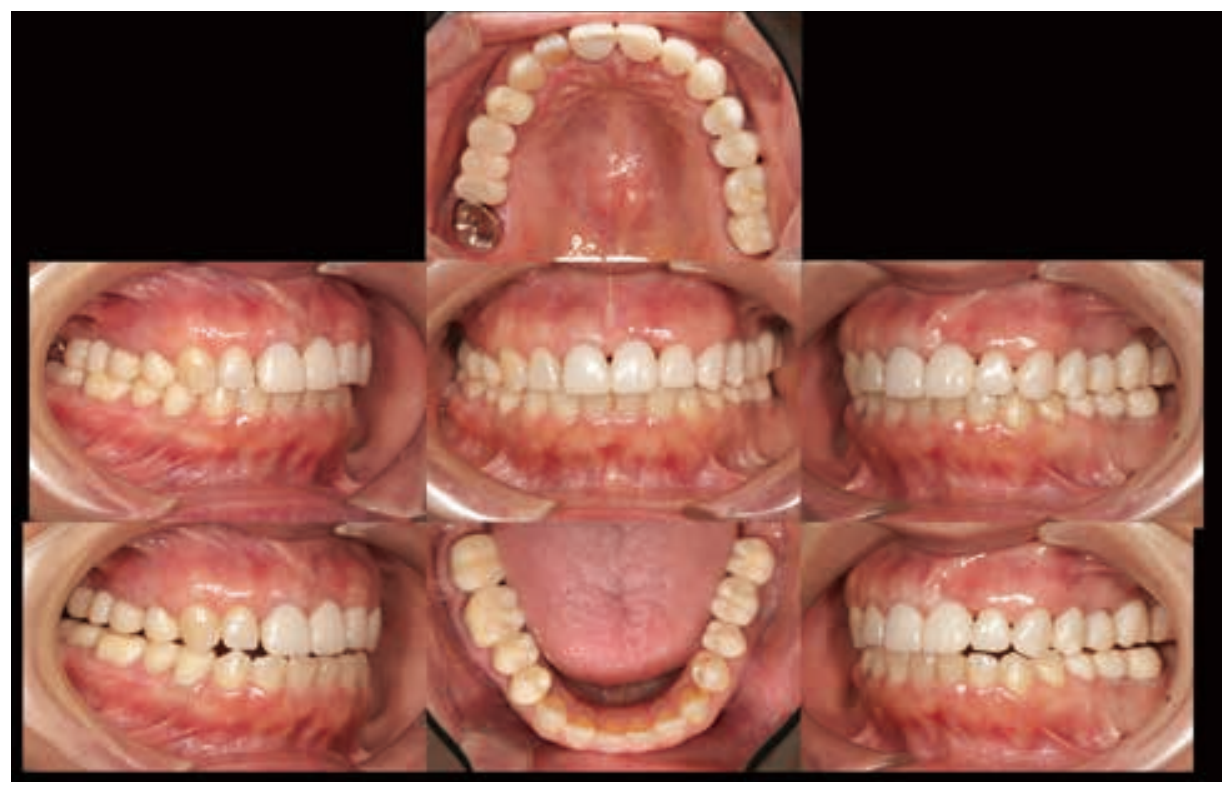

図 13 セカンドプロビジョナルレストレーション

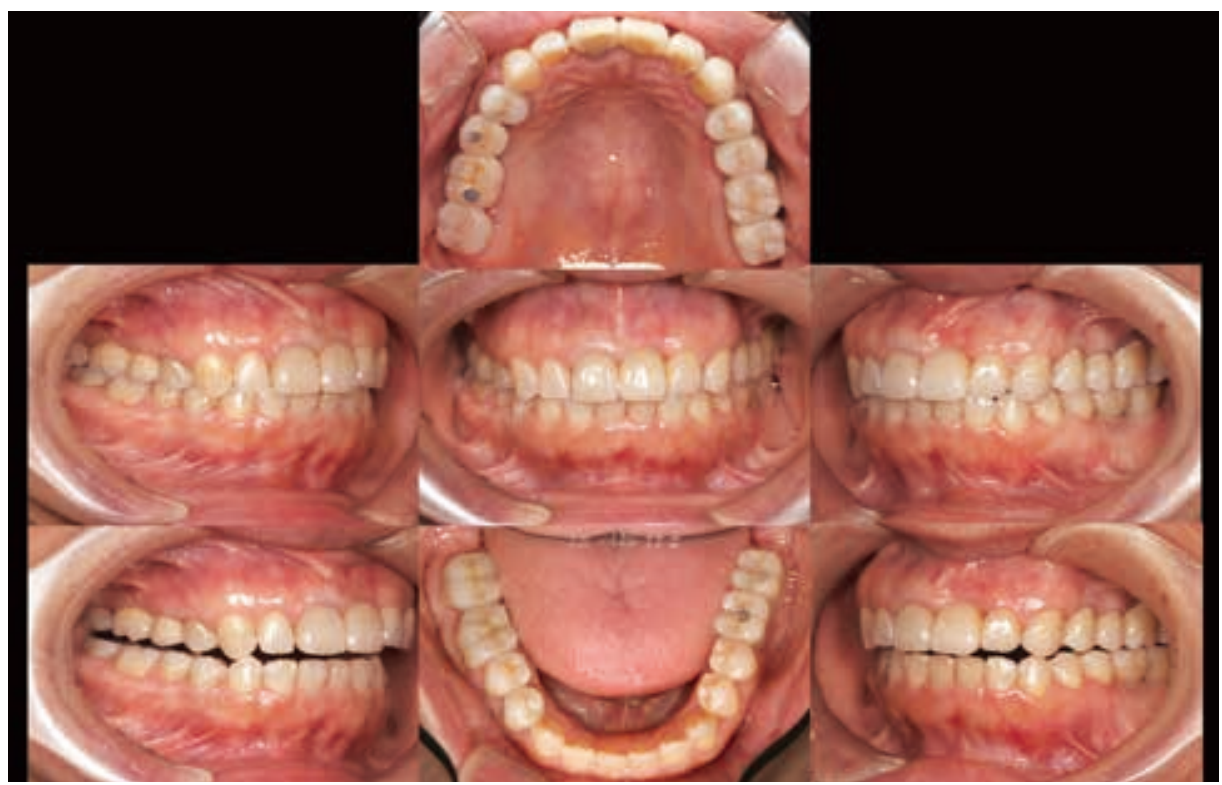

図 14 最終補緅物装着時の口腔内写真 


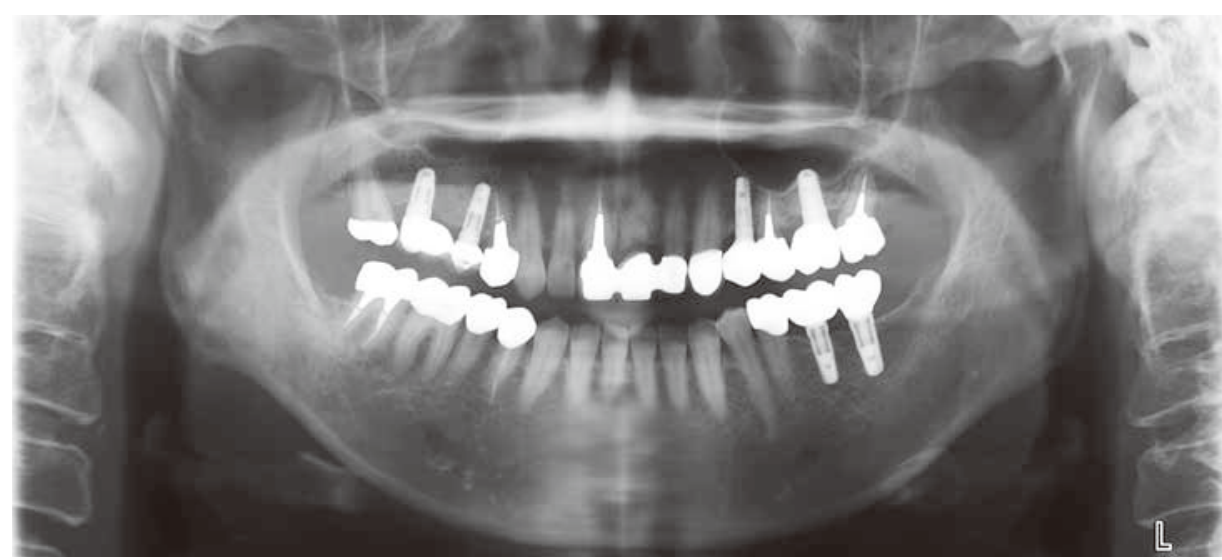

図 15 最終補緅物装着時のパノラマエックス線写真

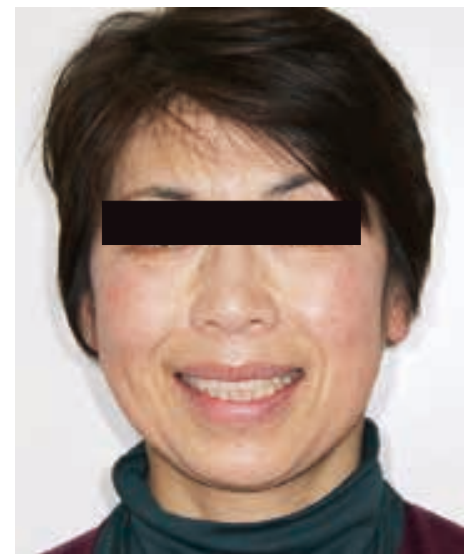

図 16 最終補緅物装着時の正面 顔貌写真

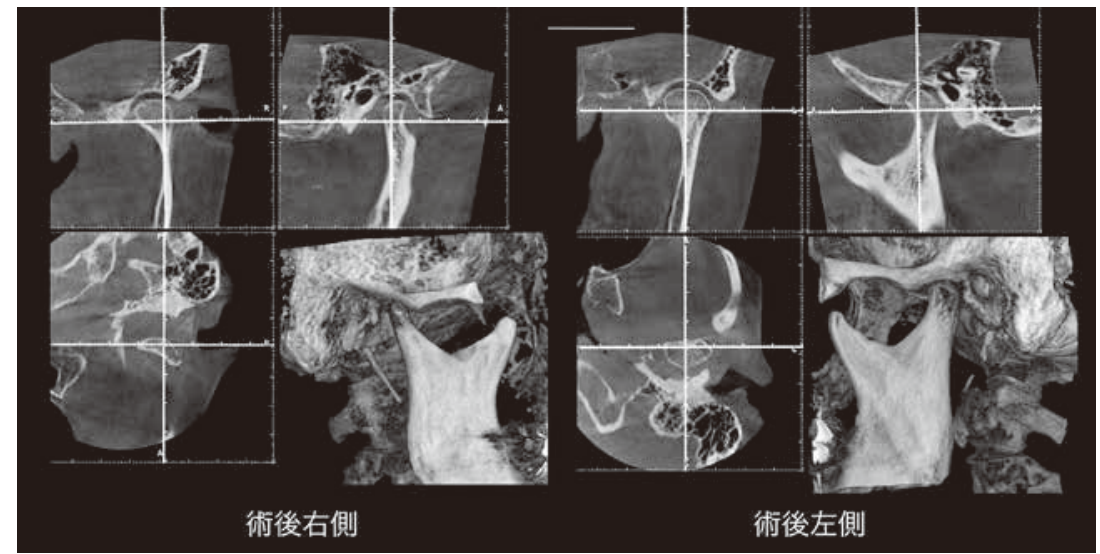

図 17 最終補緅物装着後の顎関節 CT 像
関節の維持・安定, (3)前歯部の審美性の回復, (4)咬合高 径および上下顎の水平的な位置関係の温存, (5)前歯部誘 導路の付与が獲得でき, 良好な結果が得られた。ナイト ガードを装着し, 現在術後 2 年経過している.

\section{結果と考察}

初診時, 正中線はわずかに左側に偏位が認められたが (図 1)，咬頭嵌合位と顆頭安定位のズレを確認したとこ ろ, ほとんど差異が認められなかったことと, プロビ ジョナルレストレーションで経過観察を行った結果, 安 定していると判断できたため上下正中のわずかな偏位は 許容範囲内と診断した。

本症例は臼歯部の歯冠長が短く, 術前の咬合高径を維 持するのか, 咬合を挙上して最終的な修復治療を目指す かの判断が難しいところであった。 その診断の鍵のな るのが診断用ワックスアップである. 貞光 ${ }^{9)}$ は診断用
ワックスアップは, 治療のゴールを視覚的に具現化する とともに，そのゴールが実現可能なものか, そしてゴー ルに向かうためにはどのような治療を行えばよいのかを 診査・診断すると共に, 患者に治療計画を説明し, 了解 を得るためのコミュニケーションツールでもあると述べ ている．本症例において咬合高径を挙上した診断用ワッ クスアップ（図 10）を確認すると， 臼歯部の歯冠長が 回復され標準的であるが, 本症例は明らかに咬合高径が 低下しているわけでもなく，過蓋咬合でもない，咬合高 径を維持した状態（図 8) でも自歯部離開が獲得できる と診断できた，顎関節に症状はなく，可能であれば咬合 高径を維持したいと考えた。特に右側は既存の犬歯誘導 を温存でき, 神経, 筋肉, 顎関節に対しても変化させ ないほうが望ましいともいえる。既存の咬合高径を挙上 して治療をするか否かを患者と相談した結果, 患者自身 が可能な限り歯を削りたくないと希望されたこともあり， 既存の咬合高径で最終補綴を行うこととした。

前歯部の審美に関しては 1 が歯根破折しており，特に 
唇側の骨吸収が大きく骨補塡材を用いソケットプリザ ベーションを行ったが唇側の骨吸収を抑えるには困難な 状態であったため, サージカルガイドよりも歯冠長が長 くなってしまった. 11の歯冠延長術で審美的に改善する には唇側の骨をかなり削合する必要があり歯冠歯根比の 問題からも，最小限の外科的侵襲にとどめた，著者らの 治療コンセプトの一つには, できるだけ既存の歯や骨等 の侵襲を最小限に留めることであり, このような結果で 終えた。

緒言で述べた五つの項目，(1)臼歯部における咬合の安 定はインプラントを埋入することにより獲得できたと考 える. (2)顎関節（図 4）の形態は左側の下顎頭に比較し て右側が小さく見えるが, これは先天的なものなのか後 天的なものなのかは診断出来ない. 幸いにも術前からク リックや開閉口時の偏位等, 異常な症状が認められな かったので正常に機能していると判断した. 顎関節の術 前（図 4）と術後（図 17）のCT 像を見比べても，下 顎頭の関節窩内の位置関係に大きな変化は認められず, 顎関節の維持・安定が得られたと思われる. (3)審美的回

\section{参考文献}

1）河野正司: 咀嚼機能を支える臨床咬合論, 158-164, 医歯薬 出版 (東京), 2010.

2）中野雅徳, 坂東永一: 咬合学と歯科臨床, 216-240, 医歯薬 出版(東京), 2011.

3) 今井俊広, 今井真弓：臨床咬合補綴治療, 185-200, クイン テッセンス(東京), 2018.

4) Dawson P: Functional Occlusion From TMJ to Smile Design: 114-129, Mosby-Elsevier, St.Louis, 2007.

5) Ricketts RM: Planning treatment on the basis of the facial pattern and an estimate of its growth. Angle Orthod, 27:
復に関しては1|1歯頸部において若干不揃いは認められ るものの，患者は幸いローリップでもあり審美的には 問題がない範囲である。縦横比も術前の1が 1.25 から 0.95 に, 左上中切歯が 1.14 から 0.86 と改善が認められ た. (4)咬合高径については前述した通りで，水平的な位 置関係もセカンドプロビジョナルレストレーションで充 分に経過観察を行った. (5)前歯部誘導路の付与に関して は，前方滑走時に左右臼歯部の咬合紙が抜けることから， 臼歯が離開していることを確認しており，右側は既存の 誘導路を温存したため予後経過は安心できる. 以上から 長期的な予後が期待できる咬合再構成を行えたと考える. 治療後まだ 2 年と短い期間しか経っていないので長期 的な安定を云々と言うことはできないが，咬合および歯 周組織の安定は得られていると考える. 今後へ予後経過 を注意深く追っていきたい.

謝辞

稿を終えるにあたり, 平素よりご指導いただいている貞光謙一 郎先生に深く深謝いたします。

14-37, 1957.

6）白井敏雄：口腔周囲における硬軟両組織側貌形態の比較検 討について. 歯学, 62: 625-648, 1974.

7）島田卓也, 貞光謙一郎, 福山房之助ほか: 天然歯形態を把 握する 第1報 前歯部における歯冠長径および幅径からの考 察. 歯科審美, $25(1):$ 18-24, 2012.

8）菅野博康：臨床で求める無歯顎者の下顎位と下顎誘導法. 顎咬合誌, $22(4)$ : 394-405, 2002.

9）貞光謙一郎：日本人に適した審美修復治療の理想と実際： 8-27, 医歯薬出版 (東京), 2017. 